\title{
WAYS OF IMPLEMENTING CORPORATE SOCIAL RESPONSIBILITY IDEA IN SHIPPING COMPANIES
}

\author{
NATALIA WAGNER \\ Maritime University of Szczecin, Faculty of Economics and Transport Engineering, POLAND \\ e-mail: n.wagner@am.szczecin.pl
}

\begin{abstract}
\begin{tabular}{l|l} 
RECEIVED & 2 August 2017
\end{tabular}
ACCEPTED $\quad 15$ December 2017

JEL

CLASSIFICATION

M14, R40

KEYWORDS sustainability, Corporate Social Responsibility, container shipowner, shipping

ABSTRACT $\quad$ Creating a CSR strategy and preparing a sustainability report has become more and more popular among a wide range of branches including the blue economy. The aim of the paper is to identify joint maritime industry initiatives promoting socially responsible shipping companies and to point out areas of interest for Corporate Social Responsibility raised by shipowners. The research question was asked about the identification of possible ways of understanding and implementing sustainable ideas in shipping companies operating in container market. In order to answer that question the multi-case study of container shipowners was prepared. Significant disparities in the approach to CSR are evident. They depend on the specificity of the company, primarily on the size of tonnage at disposal and market presence strategies. Leading shipping companies in the field of CSR are shipowners with significant market shares. They refer to CSR standards, participate in sustainable shipping initiatives, create coherent strategies that skilfully combine environmental, social and business goals.
\end{abstract}

\section{Introduction}

The aim of the paper is to identify joint maritime industry initiatives promoting socially responsible shipping companies and to point out areas of interest for Corporate Social Responsibility (CSR) raised by shipowners. The research question was asked about the identification of similar actions taken by shipowners that can be 
considered as typical solutions for these entities. The paper focuses on the activity which is an inseparable part of the main business of shipping companies.

\section{GSR initiatives in the shipping market}

CSR is becoming more and more important for entities from various industries, also for those operating in the shipping market. However enterprises do not always implement this idea in an identical way. The nomenclature used is also not uniform. There are several terms which are connected with CSR and very often they are used interchangeably. For instance one can find: environmental responsibility, social responsibility, sustainable development, sustainability, corporate citizenship, green marketing or triple bottom line. Regardless of the term, the intent is to reflect business responsibility for the wider societal good (Crittenden, Crittenden, Ferrell, Ferrell, Pinney, 2011).

The growing importance of the sustainability concept created a need to give it operational character and provide implementation instructions for organizations and enterprises. Such guidance is provided e.g. by International Organization of Standardization (ISO) in ISO 26000: 2010. It declares that implementing its guidance should bring benefits for companies. Also EU insists on implementing CSR approach in companies and convinces them that addressing CSR issues is in their interests. EU defines CSR as "the responsibility of enterprises for their impacts on society" (European Commission, 2011). The core subjects of CSR are: environment, labour practices, human rights, combating corruption, fair operating practices, consumer issues and community involvement (ISO, 2010)

Shipowners rarely provide information on the implementation of CSR strategies based on ISO 26000. When presenting their CSR activities shipping companies often refer to international standards such as UN Global Compact, UN Sustainable Goals or GRI Global Reporting instead of ISO 26000. Among the analysed shipowners, only CMA CGM mentions taking into account the suggestion of ISO 26000 in its activities.

The literature on CSR in shipping is scarce (Yliskylä-Peuralahti, Gritsenko, 2014). Especially there are not many research papers studying CSR as a comprehensive concept applied in shipping. It is easier to find research that focus on particular aspects of sustainable shipping. Most of them concentrate on topics such as air pollution by ships (Psaraftis, Kontovas, 2013), working conditions of seafarers (Lundh, Lützhöft, Rydstedt, Dahlman, 2011), piracy, decision transparency or improving an image of shipping industry (Theotokas, Biassias, 2014). Some issues regarding CSR in shipping can be found also in studies devoted to application of sustainability in sea ports (Gibbs, Rigot-Muller, Morgan, Lalwani, 2014) and in supply chains (Wolf, Seuring, 2010). Good practices and examples presented in literature often go beyond the legislative requirements in force. It creates a link between these ideas and CSR concept.

It is important to remember that company's activity can be identified as CSR-related only when it is based on self-regulations that are more strict than it is required by law. Therefore, in order to confirm that the shipowner's actions in the area of pollution prevention by ships are consistent with CSR, it should be demonstrated that his decisions are more stringent than the minimum required by law. The assessment of the shipowner in this respect is facilitated by the initiatives of several organizations. Such institutions promoting the sustainable development of ports and shipping industry create a number of tools useful for assessing shipowners or individual ships. The most well-known examples of such indicators are shown in Table 1. Each of these tools promotes activities carried out with higher environmental standards than required by law. The most popular is ESI programme (last row in Table 1). 
Table 1. Examples of tools for assessing the pro-environmental nature of ships and shipowners

\begin{tabular}{|c|c|c|}
\hline $\begin{array}{l}\text { Assessment and } \\
\text { certification entity }\end{array}$ & Tool name & Tool description \\
\hline $\begin{array}{l}\text { Clean Cargo Working Group } \\
\text { (CCWG) }\end{array}$ & CCWG Performance Metrics Tool & $\begin{array}{l}\text { The assessment covers shipping companies, shippers and logistic shipowners } \\
\text { involved in container shipping by sea in terms of points achieved in } 6 \text { categories: } \\
\mathrm{CO}_{2}(1), \mathrm{SO}_{\mathrm{x}} \text { and } \mathrm{NO}_{\mathrm{x}} \text { emissions (2), waste and water management (3), chemicals } \\
\text { (4), environmental management (5) and transparency of activities (6). The rated } \\
\text { companies are compared to industry standards }\end{array}$ \\
\hline Clean Shipping Project & Clean Shipping Index & $\begin{array}{l}\text { It assesses both ships and shipping companies. Shipowners enter information } \\
\text { about their ships into the database with an online tool. It is possible to compare } \\
\text { the results for individual ships or shipowners, and separately for } 5 \text { categories: } \\
\mathrm{SO}_{x} \text { and } \mathrm{PM}(1), \mathrm{NO}_{x}(2), \mathrm{CO}_{2} \text { emissions (3), chemicals and water management } \\
\text { (4) and waste management (5). The members of the project are also shippers } \\
\text { who can use the index when deciding on choosing the shipowner }\end{array}$ \\
\hline RightShip & GHG Emissions Rating & It rates ships for energy efficiency and emissions \\
\hline Green Award & Green Award Certificate & $\begin{array}{l}\text { The ship is awarded a certificate for environmental and safety measures that } \\
\text { exceed minimum legislation. Certification must be audited at the shipowner's } \\
\text { headquarters and on ships }\end{array}$ \\
\hline World Port Climate Initiative & Environmental Ship Index (ESI) & For ships that exceed IMO requirements in the field of emission reduction \\
\hline
\end{tabular}

Source: Adapted from: Andersson, Brynolf, Lindgren, Wilewska-Bien (2016), Coady, Lister, Strandberg, Ota (2013), Green Award (2017).

\section{Methodology}

The analysis of CSR topics of shipping companies was carried out for container shipowners. This is determined by three reasons. The first is high dynamics of growth of seaborne container trade (ISL, 2017). Secondly, container ships are vessels with the highest levels of GHG emissions among all types of ships (IMO, 2015). This contributes to the highest expectations of the public regarding the reduction of air pollutants. The third reason is the structure of this market, which due to the high degree of concentration of entities, shows the symptoms of oligopoly. This structure will grow stronger as the largest container shipowners strengthen their presence in the market. Top five carriers will control nearly 60\% of the world's containership fleet by 2021 (Port Technology, 2017). Market concentration is compounded by takeovers and mergers as well as operational alliances, which offer customers a joint shipping service. The large share of the main shipping companies in the container market means that the analysis of the implementation of the CSR concept by the five largest shipowners is also a study of the trends prevailing in this market.

In order to answer the research questions the multi-case study of selected container shipowners was prepared. Interesting part of the methodology is the way the companies for comparison were selected. It was done using a shipowners' ranking which enables to verify if the CSR actions depend on a shipowner's size.The selection of companies for the study is based on the ranking of the 100 largest container shipowners by total TEU capacity published by Alphaliner (Alphaliner, 2017). The first five largest shipowners were compared to those in positions 50 54 and the last five places in the ranking. The comparative analysis is based on information provided by shipowners in reports and on websites as well as articles published in shipping magazines. The content analysis based on company's web pages and sustainability reports is quite popular in the field of CSR research. This methodology can be found in papers analysing other industries and sectors (Liao, Xia, Wu, Zhang, Yeh, 2017). 


\section{Popular topies among shipowners in the CSR area}

The study was designed to outline similarities and differences in terms of CSR activities realised by selected shipowners. Table 2 provides information on the CSR strategy pursued by analysed companies.

Table 2. CSR actions taken by analysed companies

\begin{tabular}{|c|c|c|c|c|c|c|}
\hline \multirow{2}{*}{$\begin{array}{l}\text { Alphaliner } \\
\text { top } 100 \\
\text { position }\end{array}$} & Shipowner & $\begin{array}{l}\text { Total capacity } \\
\text { (thousand TEU) }\end{array}$ & $\begin{array}{c}\text { UN Global } \\
\text { Compact } \\
\text { participant }\end{array}$ & $\begin{array}{c}\text { CSR activities } \\
\text { presented } \\
\text { on the website }\end{array}$ & Carbon calculator & ESI participant \\
\hline & 1 & 2 & 3 & 4 & 5 & 6 \\
\hline 1 & MAERSK & 3505 & Yes & Yes & No & Yes \\
\hline 2 & MSC & 3059 & No & Yes & Yes & Yes \\
\hline 3 & CMA CGM & 2382 & No & Yes & Yes & Yes \\
\hline 4 & $\operatorname{cosco}$ & 1768 & Yes & Yes & Yes & Yes \\
\hline 5 & Hapag-Lloyd & 1498 & No & Yes & Yes & Yes \\
\hline 50 & MILAHA & 19 & No & No & No & No \\
\hline 51 & Crowley Liner Services & 16 & No & Yes & No & No \\
\hline 52 & FESCO & 16 & No & No & No & No \\
\hline 53 & Westwood Shipping Lines & 16 & No & No & No & No \\
\hline 54 & Far Shipping & 16 & No & No & No & No \\
\hline 96 & Harbour-Link Group Bhd & 5 & No & Yes & No & No \\
\hline 97 & Imoto Lines & 5 & No & Yes & No & No \\
\hline 98 & Grupo Susa & 5 & No & No & No & No \\
\hline 99 & Admiral Feeder Line & 5 & No & No & No & No \\
\hline 100 & ADNATCO & 5 & No & No & No & No \\
\hline
\end{tabular}

Source: own study based on websites of presented companies and: Mediterranean... (2017), CMA CGM (2016), Moller-Maersk (2016), COSCO Shipping (2016), World... (2017), United Nations Global Compact (2017).

The information about shipowners' actions (column 4 in Table 2) were taken into account in one of the three main areas, i.e. environment, employees or community. As a confirmation of implementation of CSR strategy the information about concrete actions was taken into account, not merely general assurances of the importance of these issues in the operation of the company, which are not supported by any examples.

Table 2 indicates that the top five shipowners are more likely to formulate a CSR strategy, participate in international sustainable shipping initiatives and report on their activity in this area. The most detailed reports, Sustainability Reports, are published by Maersk and COSCO. In case of COSCO the content refers to the guidelines proposed by the GRI. The CMA CGM publication is entitled Code of Ethics, the Hapag-Lloyd is Global Code of Ethics, and the MSC is Code of Business Conduct. They are sets of rules of behaviour in the corporation rather than real CSR reports. In any case, the scope of the report covers the entire capital group, not just the container shipowner.

Analysis of sustainability reports and the content of container shipowners' web pages allows to identify the main areas that are most frequently repeated in CSR strategies. Figure 1 presents the ones that relate to the specificity of functioning on the freight markets. Those that are general (such as anti-corruption policy, charity, supporting local communities) and could concern businesses in any other industry are omitted. 


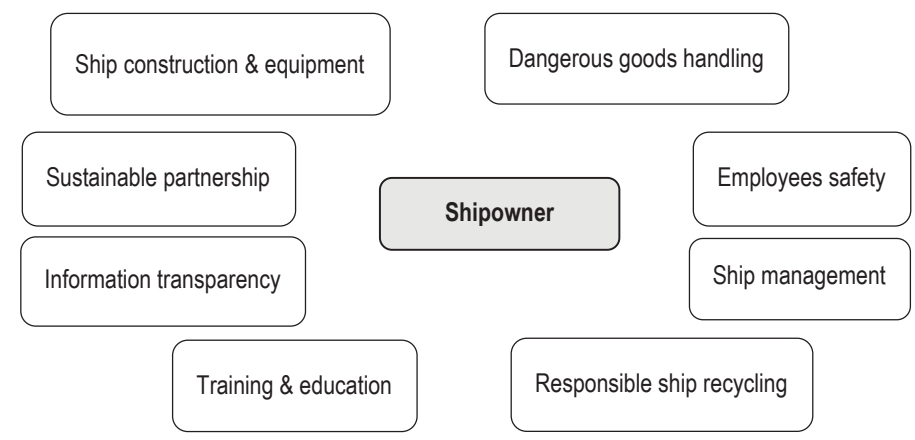

Figure 1. Key areas of interest for shipowners in the field of CSR

Source: own work.

The CSR concept is about integrating environmental and social issues into business, while taking into account stakeholder expectations. However, according to the information published by the shipowners, many of them focus mainly on the issues of conservation of the marine environment and fight against climate change. The information on social involvement is largely limited to the presentation of charity. The issue of identifying and analysing stakeholder expectations is also rarely discussed. Even among the first five largest container shipowners this process is described only by COSCO.

The decision to implement the CSR strategy should be related to a general strategy of the company's presence in the shipping market (Goss, 2008), the scale of its business and relationships within the shipping business group. From this standpoint, several typical categories of shipowners can be distinguished (Table 3 ).

Table 3. Most typical categories of analysed shipowners according to their size, presence in the container shipping market and attitude toward CSR

\begin{tabular}{lcccc}
\hline \multicolumn{1}{c}{ Dimension } & Category 1 & Category 2 & Category 3 & Category 4 \\
\hline Large market share & Yes & No & No & No \\
Long term presence in the market & Yes & Yes & Yes & No \\
CSR formal strategy & Yes & No & No & No \\
Only few CSR actions & No & Yes & No & No \\
\hline
\end{tabular}

Source: own work.

The first one is composed of big companies operating within diversified business groups, which often represent several brands. This type of business most often develops and implements a formal CSR strategy, characterized by precisely defined objectives, methods and reporting effects in the form of CSR reports. These companies are the most recognisable by the public, hence their positive image is of great importance. This group has the leading position in Table 1. For further categories the scale of services is definitely smaller and the market share is lower. In the case of small shipowners, CSR approach is not indicated as a priority, and even if it is mentioned, it is more intuitive than described in the documents. Applying or abandoning the implementation of the CSR concept depends to a large extent on their business objectives, i.e. long-term presence on the market or entering the market only for 
making quick profits. There are also entities concentrated only on financial aspects of doing business. Their activity on the freight market is closely related to the business cycle in shipping. Their objective is to achieve the highest possible profit in the short term. Such shipowners are not interested in implementing the CSR concept at all.

\section{Conclusions}

It is extremely difficult to compare the implementation of a CSR strategy implemented by several companies. This is because CSR activities are undertaken voluntarily, cover many aspects of business operations and the standards only provide general guidelines and recommendations to facilitate their application. Specific actions must already be individually tailored to the industry and specificity of the business.

It is essential to carefully implement CSR principles for core business. For the shipowner this activity is sea transport, and the basic work tool - a ship. The article identifies CSR activities typical of shipping shipowners as: sustainable ship management and integrating sea transport into the "green supply chain" as well as ship design with the main aim of minimizing pollution, increasing energy efficiency, ensuring ship and crew safety. In addition, an important area of implementation and one of the biggest challenges faced by the shipping industry is the application of CSR throughout the whole ship life cycle - during shipbuilding process, fleet management and ship recycling.

Significant disparities in the approach to CSR are evident. They depend on the specificity of the company, primarily on the size of tonnage at disposal and market presence strategies. Leading shipping companies in the field of CSR are shipowners with significant market shares. They act according to CSR standards, participate in sustainable shipping initiatives, create coherent strategies that skilfully combine environmental, social and business goals, publish CSR reports and, above all, have "green" ships.

\section{Acknowledgements}

Research outcomes obtained as a result of a research study entitled "The concept of Corporate Social Responsibility in transport, forwarding and logistics market" no. 7/S/IZT/2017 financed with a subsidy from the Ministry of Science and Higher Education for financing statutory activity.

\section{Referenences}

Alphaliner (2017). Retrieved from: https://alphaliner.axsmarine.com/PublicTop100 (20.05.2017).

Andersson, K., Brynolf, S., Lindgren, J., Wilewska-Bien, M. (2016). Shipping and the Environment: Improving Environmental Performance in Marine Transportation. Berlin: Springer.

CMA CGM (2016). Code of Ethics CMA CGM GROUP. Retrieved from: http://www.cma-cgm.com/the-group/corporate-socialresponsibility/environment (8.07.2017).

Coady, L., Lister, J., Strandberg, C., Ota, Y. (2013). The Role of Corporate Social Responsibility in the International Shipping Sector. A Phase 2 Research Paper. The Northern European Symposium on CSR Shipping. Copenhagen.

COSCO Shipping (2016). COSCO Shipping Sustainability Report 2016.

Crittenden, V., Crittenden, W., Ferrell, L., Ferrell, O., Pinney, C. (2011). Market-oriented sustainability: a conceptual framework and propositions. Journal of the Academy of Marketing Science, 39, 71-85.

European Commission (2011). A Renewed EU strategy 2011-2014 for Corporate Social Responsibility. COM (2011) 681 final, Brussels.

Gibbs, D., Rigot-Muller, P., Morgan, J., Lalwani C. (2014). The role of seaports in end-to-end maritime transport chain emissions. Energy Policy, 64, 337-348.

Goss, R. (2008). Social Responsibility in shipping. Marine Policy, 32, 142-146.

Green Award (2017). Retrieved from: www. greenaward.org (2.06.2017). 
IMO (2015). Third IMO Greenhouse Gas Study 2014. London.

ISL (2017). Shipping Statistics and Market Review, 5-6. Bremen.

ISO (2010). ISO 26000:2010. Guidance on social responsibility.

Liao, P., Xia, N., Wu, C., Zhang, X., Yeh, J. (2017). Communicating the corporate social responsibility (CSR) of international contractors: Content analysis of CSR reporting. Journal of Cleaner Production, 156, 327-336.

Lundh, M., Lützhöft, M., Rydstedt, L., Dahlman, J. (2011). Working conditions in the engine department - A qualitative study among engine room personnel on board Swedish merchant ships. Applied Ergonomics, 2 (42), 384-390.

Mediterranean Shipping Company (2016). MSC Code of Business Conduct. Retrieved from: https://www.msc.com/grc/sustainability/ governance (1.07.2017).

Moller-Maersk, A.P. (2016). Sustainability Report 2016. Retrieved from: http://www.maersk.com/en/the-maersk-group/sustainability (10.07.2017).

Port Technology (2017). Retrieved from: https://www.porttechnology.org/news/top_five_carriers_to_control_over_half_of_container_ shipping_by_2021 (21.06.2017).

Psaraftis, H., Kontovas, C. (2013). Speed Models for Energy - Efficient Maritime Transportation: A Taxonomy and Survey. Transportation Research Part C, 26, 331-351.

Theotokas, I., Bissias, I. (2014). A Touch of Salt: The Image of Shipping in Newspapers of the UK. WMU Journal of Maritime Affairs, $2(13), 177-190$.

United Nations Global Compact (2017). Retrieved from: https://www.unglobalcompact.org/what-is-gc/participants (18.06.2017).

Wolf, C., Seuring, S. (2010). Environmental impacts as buying criteria for third party logistical services. International Journal of Physical Distribution \& Logistics Management, 1 (40), 84-102.

World Ports Sustanability Program (2017). Retrieved from: http://esi.wpci.nl/Public/Ships (3.07.2017).

Yliskylä-Peuralahti, J., Gritsenko, D. (2014). Binding rules or voluntary actions? A conceptual framework for CSR in shipping. WMU Journal of Maritime Affairs, 2 (13), 251-268.

Cite this anticle aS: Wagner, N. (2018). Ways of implementing Corporate Social Responsibility idea in shipping companies. European Journal of Service Management, 2 (26), 315-321. DOI: 10.18276/ejsm.2018.26-39. 